\title{
Letter to Parents: The Purpose of College
}

\author{
Libby V. Morris ${ }^{1}$
}

Published online: 27 March 2017

(C) Springer Science+Business Media New York 2017

(A letter to the parents of traditional students in colleges and universities everywhere.)

We want your son or daughter (and even you) to come to our college! We want to enroll you, retain you, graduate you, and then send you on to your next career step! That is the simple definition of college success!

Let's first think about enrollment. Across the breadth of our 2-year and 4-year colleges and research universities, we embrace college access. We focus on recruiting a diverse group of students, like the kind your son or daughter will live with and work with in their future. We believe that diversity in the classroom will provide students with the experiences, insights, and competencies needed for a successful future. We also collectively advocate for more federal aid through our federal and state lobbyists and contribute to institutional scholarships to assist in paying for college, if you need that help. We know that many do and that the debt on graduation may be large for some. We are concerned about this problem, and scholars have produced a lot of research about this issue.

We are also focused on retention and graduation. If you come to our college, we want you to stay and graduate. We therefore have joined a number of national initiatives like Complete College America, which sets state goals for graduation and encourages institutions to track progress and reduce obstacles to retention; yes, you should ask about completion rates when weighing which institution to attend. In fact, there are a lot of associations and agencies that are concerned about improving the pathways to graduation; and our colleges heavily invest in educational technologies to support instruction and student achievement. These professional associations and educational consultants all focus on some aspect of the process of education (e.g., improving teaching, using online technologies, restructuring advising, tracking courses and credit hours). Our advocates and leaders know that by enhancing the process, we can improve retention and graduation. So, our college administrators are increasingly focused on and proficient at measuring student progress toward graduation and in linking a number of metrics and analytics to identify problems and predict success; that is all good.

Concerning the process, your child (soon to be our student!) will have a lot of choices in what to study. To adapt to student interests and the growth of knowledge, we now strive for

Libby V. Morris

1vmorris@uga.edu 
comprehensiveness, like a grand buffet of program choices. One small problem crept in, however, and this is actually the point of my letter to you. Now don't worry, our college holds accreditation; and whatever your child selects, she or he is likely to receive a solid degree. The question is, what type of education will your child receive? What will he or she learn? For now and for the future? Will they enroll in college (and pay) only to receive 2 to 4 years of job training?

Unfortunately, in our intense focus on access, progression, retention and graduation, we might overlook the most important reason for going to college: learning - what will they learn? Now without too much of a digression, student learning outcomes are developed for all majors and programs; but, beyond specialized knowledge, what are the overarching learning outcomes that characterize a college education? An educated populace and educated person? Will your child achieve these outcomes, too?

Today, all too often, internal and external entities, groups, and individuals see the purpose of college as job training. A lot of our best supporters and contributors want students to receive specific career training, which is sometimes called workforce development; and they may see colleges as drivers in economic development. I get it - the economy needs skilled workers; and students want and need jobs, especially considering the cost of education. With my English major, I wanted a job after graduation, too. Yet, over the last three decades, more and more students have chosen a narrow track of study; and college is just another achievement on the way to somewhere else. Robots are also being built to do a wide range of tasks, so I will leave that for you to consider on your own.

The changing role of education cannot be dumped at the feet of corporate America or consumers (oops...I meant students) alone. As knowledge increased, faculty groups organized around specializations; and even more narrowly-focused degrees emerged. In this process, I wonder if we have failed to collectively consider and articulate the fundamental and foundational purpose of college to our students, constituents, legislators, employers, parents, and society.

Now, more than ever, during college our students (your children) should have room to think about who they are, how we live and work and love and die, and our roles in relationship to others and even to the world. Let's not let college be either-or. College is about preparing for life — all of life - worker, parent, community member, leader, in sum.... Preparing for a welllived life.

Most employers identify critical thinking as the competency most valued in employees. However, somehow, in becoming comprehensive in degree offerings, in equating success in the process with a meaningful education, we took a detour to a utilitarian view of education. What kind of job does it lead to? And what will it pay? We not only allowed, we encouraged specialization at the undergraduate level; and we did not insist on a humanities infused education. With the emphasis on testing and measuring, we prioritized knowledge over the deeper goals of competence and understanding - the what, how, and why, respectively.

We need your help. Across the world, millions of people are displaced due to wars and famines. Thousands, including women and children, are homeless and hungry, including persons in our own country. Violence takes place in targeted ways in shopping malls and in theaters and in massive ways in military attacks and mass killings. Violence, hunger, pollution, disease, homelessness - the ills of societies are waiting for people solutions - collaborative and negotiated solutions, visionary solutions, solutions arising from deep thought and communication with each other.

Please encourage your student, your child, to consider getting a college education, not just a degree - to grab the opportunity to read deeply, to understand difference, to respect free 
speech, to learn from the opinions of others, and to understand that adversaries need not be enemies. My speculation is that the grand problems of this small globe will not be solved by just another piece of technology, or another investment instrument, or a high rise corporate or residential project, or even another app. The problems of the world, that we all share in common - the need for clean air and food and water, safe housing and health care, loving families and friends - must first be addressed by those with an understanding of humankind, the skills to engage in those dialogues and difficult conversations, the wisdom to engage technologies and professional knowledge, and the faith to envision a better future.

I hope that your child will be the change-maker, that you will encourage your son and daughter to take on this bigger challenge. We will then launch the technologies, the builders, the bakers, the caretakers - in service to us all.

I apologize that we have allowed a holistic vision of what education could be for your child to slip away over the last century. I commit to asking all of my faculty friends-humanists, scientists, social scientists, all - to consider this question anew: What are we educating for? How can we join the deep understandings developed through the humanities with the rapidly changing knowledge produced in the specialized and professional fields? With our experience, you and I know that life is not either-or.

Sincerely,

Dedicated faculty member 